\title{
STUDYING THE EFFECT OF COLLABORATIVE DIALOGUE TECHNIQUE ON GRADE TENSTUDENTS' VOCABULARY ACQUISITION
}

\author{
Nurul Hasanah Fajaria ${ }^{1}$, Sumayah Asy-Syarifah ${ }^{2}$
}

Universitas Islam As-Syafi'iyah Jakarta

\begin{abstract}
This study examines the effect of using collaborative dialogue technique on EFL learner's vocabulary acquisition at SMA Tunas Markatin Rawamangun. The purpose of this research is to find out whether or not there is the effect of using collaborative dialogue technique on students' vocabulary acquisition. The subject consisted 50 students and divided into two classes (experimental class and control class), consist of 25 students in each class. The sampling technique was randomize sampling. To collect data the researcher used two instruments in the form of objective multiple choice each numbering 30 for both experiment class and control class out of 60 question items for experiment class and control class having been tried out at class $\mathrm{X}$ at SMA Vinama, Bekasi. The score obtained from the try out class were used to analyze the validity, reliability, discrimination power and difficulty index of each question item in the two instruments. The analysis using SPSS-based One-Way Anova formula produced significance (Sig) value of 0.000 . Since the significant value was smaller than $(<)$ Alpha $0,05, \mathrm{H}_{\mathrm{o}}$ is rejected and $\mathrm{H}_{\mathrm{a}}$ is accepted. Accordingly the research concluded that there was significant effect of collaborative dialogue on grade ten students' vocabulary acquisition at SMA Tunas Markatin, Rawamangun in the academic Year of 2016/2017.
\end{abstract}

The key word: collaborative dialogue, vocabularyacquisition 


\section{Introduction}

Vocabulary is the key to student understanding what they hear and read in school and to communicate successfully with other people. For this reason it is very important for the student to quickly build up large store of word. Research has shown the strong links between having an extensive vocabulary and achieving school success.

Based on KTSP curriculum especially on senior high school level the objective which should be achieved by students that student should be able to communicate with English not only in written but also orally. But the actual condition in Indonesia, there is many students still failed in national examination especially in English subject and the score still low. This caused by poor of teaching technique, therefore the writer found out one of a good technique that can be used to improve students' vocabulary, it is collaborative dialogue technique. Collaborative dialogue is join construction of language or knowledge about language by two or more individuals; it's what allows performance to outstrip competence; it's where language use and language learning co-occur.Long (1981.1983), proposed that "learners can understand word beyond their present level of competence by negotiating their meanings with other learner. This collaborative act, can promote acquisition since learners eventually can incorporate the negotiated items in their production".

Swain (1995), collaborative dialogue, as one of the form of interaction, among peers can function as instructional conversation between expert and learners. This kind of dialogue provides the learners with "opportunities to construct a complex linguistics structure by focusing their attention and providing opportunities to revise their own language use" (Swain and Watanabe, 2013p. 3218). As it was 
observed in the present study, the learners in the collaborative group grasped such opportunities by asking questions, explaining their choices, and elaborating upon their knowledge. In this way, the peers tutored and mediated the learning process of their peers (Barnard, 2002, Lantolf, 2000); this resulted in a significant difference between the performance of the collaborative learners and the individual ones.

The previous relevant researches that revealed collaborative dialogue technique on students' vocabulary acquisition are: 1). Mousa Ahmadian, Majid Amerian, and Tajabadi (2014) revealed that collaborative dialogue in the context of language learning can benefit the learner's acquisition and retention of L2 vocabulary. 2). Maryam Farajee Golestan Science and Research Branch revealed that collaborative small group work is to help students' master concepts components of the course and better understand content of instructional texts. 3). Robyn M. Gillies, revealed that attention in recent years has turned to the key role talk plays in mediating students' learning when they work cooperative together.

Based on the explanation above the present study aims to investigate to the effect collaborative dialogue technique on grade students' vocabulary acquisition at SMA Tunas Markatin Rawamangun. To examine the effect of collaborative dialogue technique on grade students' vocabulary acquisition at SMA Tunas MarkatinRawamangun, the research question is formulated as follows :"Is there any effect of using collaborative dialogue technique on grade students' vocabulary acquisition at SMA Tunas Markatin Rawamangun?" 


\section{Method}

\section{Hypotheses}

Null Hypothesis (no significant effect)

Alternative Hyothesis (significant effect)

\section{Research Design}

The research design employed was randomized, posttest only control group design randomized (randomize penentuan kelas sample).The research design used in this research is post test only control group design. This design when applied specifically to this research will read as follow:

\begin{tabular}{|c|c|c|}
\hline GROUP & TREATMENT & POST-TEST \\
\hline $\begin{array}{l}\text { Experiment } \\
\text { class (X B) }\end{array}$ & $\begin{array}{l}\text { (treatment with collaborative } \\
\text { dialogue technique) }\end{array}$ & \multirow{2}{*}{$\begin{array}{l}\text { Achievement } \\
\text { Test } \\
(30 \text { good } \\
\text { question } \\
\text { items on } \\
\text { vocabulary) }\end{array}$} \\
\hline $\begin{array}{l}\text { Control } \\
\text { class (X A ) }\end{array}$ & $\begin{array}{l}\text { (verbal explanation technique } \\
\text { without collaborative dialogue } \\
\text { technique provided) }\end{array}$ & \\
\hline
\end{tabular}

\section{Particpants}

The population of this research is Grade-ten Students at SMA Markatin Rawamangun, Pulo Gadung, Kota Jakarta Timur, Daerah Khusus Ibukota Jakarta, in The Year Academic 2016/2017, consisting of 55 students divided into 2 classes, and each class consists of 25 and 30 students.

\section{Variables and Measures}

This research uses two variables; they are independent variable $(\mathrm{X})$ and dependent variable (Y).Independent variable in this research is collaborative dialogue and dependent variable is students' vocabulary acquisition. To measure students' ability 
in vocabulary acquisition, the writer took score from indicators of reading comprehension, as follows:
a. Students are able to recognized the synonim of the words $(\mathrm{C} 2)$
b. Students are able to identifed the antonim of the words $(\mathrm{C} 2)$
c. Students are able to use the word in the right context(C2)
d. Students are able to give definition of words $(\mathrm{C} 3)$
e. $\quad$ students are able to define words (C3)

\section{Validity and Reliability}

The indicators of vocabulary acquisition were developed to be instrument. The instrument was objective test with 60 items. Those items were analyzed its validityusing Pearson Product Moment Correlation Coefficient, reliabilityusing Alpha Cronbach formula, difficulty index and discrimination power to obtain good instrument using Microsoft Excel 2007. After the items have been analyzed, the good items that valid, reliable, satisfactory and medium were chosen to obtain good data. The question items were left 35 numbers. But it was only used 30 good question items to simplify the data analysis.

\section{Procedure}

\section{Planning}

The planning phase consist of Formulating the problem, reviewing the literatures correlated with the problem under study, formulating hypotheses, constructing Blue print, specifying indicators of the variable and physiological aspect, developing the indicators into research question, conducting try-out, analyzing question items in term of validity, reliability, discrimination power 
and difficulty index, establishing the research method and design and preparing lesson plan.

2. Collecting Data

The data were collected from samples by giving good instrument in the post test preceded by treatment from both the experimental classes using collaborative dialogue in experimental class and other method in control class.

3. Data Analysis

The data analyses from the samples (experiment class and control class) were then analyzed by inferential statistic of Anova preceded by pre-requisite tests to data analysis, namely, normality test and homogeneity variance.

4. Reporting

The research findings were reported by following the formal mechanism establish by faculty of teaching and educational sciences particularly by English Education study Program in the form of thesis or paper.

Table 1 : Descriptive Statistics

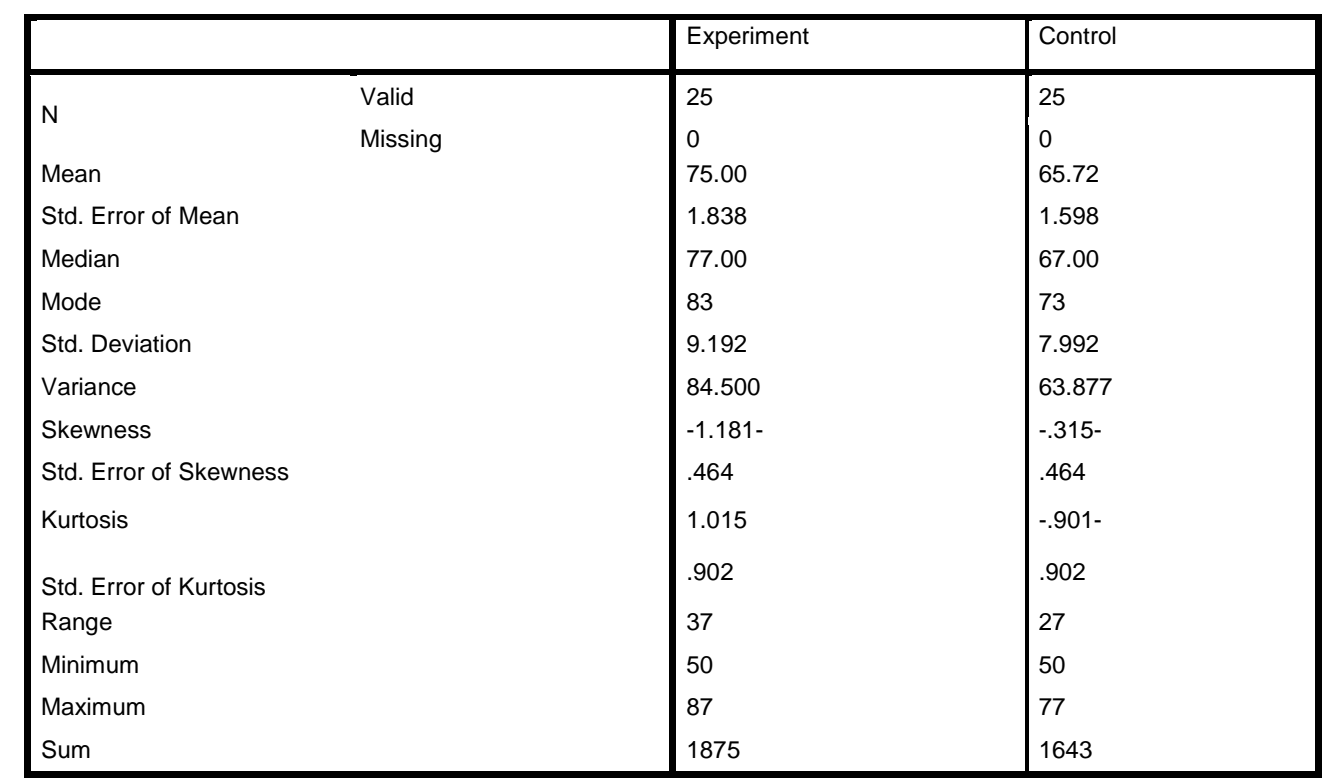




\section{Result}

The research data were analyzed descriptively and inferentially. The descriptive statistic can be seen on the following table.

Based on the data above, can be seen the value of the Mean or the arithmetic Mean for grade ten experiment and control 75.00 and 65.72. While the variance 84.500 and 63.877. Otherwise it looks range 37 and 27. Its mean that the students who were treat by using collaborative dialogue technique was get the higher score than students who were not treat by using collaborative dialogue technique.

The result of analysis data using SPSS based on One Way Anova.

Table 2 : ANOVA

\begin{tabular}{|l|l|l|l|l|l|}
\hline & Sum of Squares & Df & Mean Square & F & Sig. \\
\hline Between Groups & 1076.480 & 1 & 1076.480 & 14.510 & .000 \\
Within Groups & 3561.040 & 48 & 74.188 & & \\
Total & 4637.520 & 49 & & & \\
\hline
\end{tabular}

From the table above, can be gained that the significance 0,000 were lower than $(<) 0.05$ or $\mathrm{F}_{\text {observed }}(14.510)$ is higher than $(>) \mathrm{F}_{\text {Table }}(4.04)$. Means that there were real influences of independent variable $(\mathrm{X})$ on dependent $(\mathrm{Y})$ variable.

\section{Discussion}

The purpose of this study was to investigate the effect of learning by using Collaborative dialogue techniques on grade ten students' vocabulary acquisition at SMA Tunas Markatin in the Academic Year 2016/2017. This study was to prove the theory of Long (1981.1983), which proposed that "learners can understand word beyond their present level of competence by negotiating their meanings with other 
learner. This collaborative act, can promote acquisition since learners eventually can incorporate the negotiated items in their production".

This research verified and supported the previous relevant researches conducted by MousaAhmadia (2014), Maryam Faraje (2007) and Robyn M. Gillies (2001) about the influence collaborative techniques dialogue on the knowledge English vocabulary.

The findings of this study showed that after an experimental class got treatment using collaborative dialogue techniques, it revealed that students tend to be more active, more motivated in learning English. The results of the post-test showed that the experimental class who were taught using collaborative dialogue technique got the higher scores than those in the control class who were taught using conventional technique. However, there were the students in control class got a higher score than some students in experimental class; it was not affected by any technique (including collaborative dialogue technique) because basically the students who got the higher score in control class is a smart student.

In the implementation of collaborative dialogue techniques, the class was divided into groups, than they were given a picture or topic for discussing. With this technique all students had an opportunity to present their opinion. On the other hand the other group members will listen to the opinions of other group members, so that unconsciously they got a new vocabulary of his or her friend.

Therefore, the writer concluded that this technique can be used by schools to develop students' vocabulary knowledge. So that students have no difficulty in understanding the text or conversation in English version. 


\section{Conclusion}

The research was conducted to find out whether or not there is influence of collaborative dialogue technique on grade ten students' vocabulary acquisition at SMA Tunas Markatin, Rawamangun in the academic year of 2016/2017. As presented in chapter IV, the research has rejected null hypothesis $\left(\mathrm{H}_{0}\right)$ and accepted the alternative hypothesis $\left(\mathrm{H}_{\mathrm{a}}\right)$. Therefore, the research has proved empirically that there is effect of using collaborative dialogue on students' vocabulary acquisition on grade ten at SMA Tunas Markatin, Rawamangun. 


\section{REFERENCES}

Depdikbud.Kurikulum 1994. GBPP SMU .Jakarta: Depdikbud 1994

Depdiknas. Kurikulum 2006. Standar kompetensi Mata Pelajaran Bahasa Inggris SMA/MA. Jakarta: Depdiknas, 2006.

Long, M. (1983). Input, Interaction, and second language acquisition. In H. Winitz. (Ed.), Native Language and foreign acquisition: Annals of the New York Academy of Science (pp.259-278). New York: New York Academy and Science.

Long, M. H. (1983). Native Speaker/non-native speaker conversation and the negotiation of comprehensible input. Applied Linguistics,4(2), 126-141.

Ahmadian,M.,Amerian,M.,Tajabadi,A (2004). The Effect of Collaborative Dialogue on EFL Learner's Vocabulary Acquisition and Retention. International journal of Applied Linguistics and English Literature.

Andrew Bimiller, Teaching Vocabulary : Early Direct an Sequental.'Essential Reading on Vocabulary Instruction, ed. By Michael ,F.Graves International Reading Assosiation, 2009.

Swain, M. (1995). Three function of output in second language learning. In G. Cook and B. Seidhofer (Eds), Principles and Practice in Applied Linguistics (pp. 125144). Oxford: Oxford University Press.

Swain, M., and Lapkin, S. (2002).Talking it through: Two French immersion learners' response to reformulation.International Journal of Educational Research, 37 (34), 285-504.

Swain, M., Watanabe, Y. (2013). Language Collaborative Dialogue as A Source of Second Language Learning. In C. A. Chapelle (Ed), The Encyclopedia of Applied linguistics ( pp.3218 - 3225). Hoboken, NJ: Wiley-Blackwell.

Watanabe, Y., \& Swain, M. (2007). Effect of proficiency differences and patterns of pair interaction on second language learning: collaborative dialogue between adult ESL learners. Language Teaching Research, 11(2), 121-142. 